\title{
Pengalaman Ibu dalam Merawat Bayi dengan Prematur dan Berat Badan Lahir Rendah
}

\author{
Deswita $^{a}$ \\ ${ }^{a}$ Universitas Andalas \\ E-mail:deswitapsik@yahoo.com
}

\begin{abstract}
Taking care of the infants becomes a separate stressor especially if the infants is born with premature and infants who have low birth weight. Many problems arise, if the infants is not treated as it should lead to disability and even death. However, there are some mothers who successfully care for premature and low birth weight infants in the house. Mothers who successfully treat premature babies and low birth weight at home is a situation that is very interesting to learn, because with the new gain experience premature and low birth weight , the mother has been able to take good care. The purpose of this research is in the picture get it mother's experience in caring for premature and low birth weight infants in the house. This study used a qualitative research design with a phenomenological study. Participants of this study were mothers who have had premature and low birth weight infants in the treated at home part of Puskesmas Ambacang. Intake of participants conducted purposive sampling technique, with the number 5 . Themes were identified from the interview are as many as 5 (five). These themes are : (1) Characteristics of premature and low birth weight infants, ( 2 ) the mother 's response to premature birth and low birth weight ( 3 ) Treatment of premature and low birth weight infants in the house, (4) Support the mother in caring for premature and low birth weight infants,(5)Hope maternal health services
\end{abstract}

Keywords: premature, low birth weight, maternal experience

Abstrak: Merawat bayi menjadi suatu stressor tersendiri terlebih jika bayi lahir dengan premature dan bayi yang mempunyai berat badan lahir rendah. Banyak permasalahan yang timbul, jika bayi tidak dirawat sebagaimana mestinya mengakibatkan kecacatan bahkan kematian. Namun demikian, ada beberapa ibu yang berhasil merawat bayi premature dan BBLR di rumah. Ibu yang berhasil merawat bayi premature dan BBLR di rumah merupakan suatu keadaan yang sangat menarik untuk dipelajari, karena dengan pengalaman yang baru mendapatkan bayi premature dan BBLR, ibu telah mampu merawatnya dengan baik. Tujuan penelitian ini adalah di dapatkannya gambaran pengalaman ibu dalam merawat bayi premature dan BBLR di rumah. Penelitian ini menggunakan desain penelitian kualitatif dengan studi fenomenologi. Partisipan penelitian ini adalah ibu yang telah memiliki bayi prematur dan BBLR dirawat di rumah daerah wilayah kerja Puskesmas Ambacang. Pengambilan partisipan dilakukan tehnik purposif sampling, dengan jumlah 5 orang. Tema yang teridentifikasi dari hasil wawancara adalah sebanyak 5 (lima). Tema tersebut adalah: (1) Karakteristik bayi premature dan BBLR, (2) Respon ibu terhadap kelahiran premature dan BBLR (3) Perawatan bayi premature dan BBLR di rumah, (4) Dukungan ibu dalam merawat bayi premature dan BBLR, (5) Harapan ibu pada pelayanan kesehatan.

Kata Kunci: Bayi premature, BBLR, pengalaman ibu 


\section{PENDAHULUAN}

Bayi prematur dan bayi yang mempunyai berat badan lahir rendah (BBLR), jika tidak mengalami kematian saat atau segera setelah lahir, umumnya kelangsungan hidup bayi tersebut akan mempunyai risiko tinggi mengalami keterlambatan dan penyimpangan tumbuh kembang. Bayi prematur mengalami hambatan pertumbuhan dan perkembangan sejak masa janin, sehingga berdampak pada pertumbuhan dan perkembangan selanjutnya (Potts \& Manleco, 2007). Ketidakmatangan pada sistem-sistem organ itulah yang membuat bayi prematur cenderung mengalami kelainan-kelainan dibanding bayi normal. Selain itu bayi prematur mempunyai risiko kelainan neurologis dan gangguan belajar yang dapat ditimbulkan sampai umur 7-10 tahun (Panduan Pelayanan Medis Kesehatan Anak, 2007; 336). Bayi prematur kemungkinan lebih lambat dalam menguasai suatu keterampilan dibanding bayi lahir cukup bulan, walaupun komplikasi medis dan infeksi disebut sebagai faktor penyebab bayi lahir kurang bulan (Wijayanegara, dkk 2009).

Di Indonesia biaya perawatan bayi premature dan BBLR cukup tinggi. Umumnya bayi prematur dan BBLR berasal dari keluarga kurang mampu, sehingga tidak cukup biaya untuk melakukan perawatan bayi di rumah sakit dan memilih merawat bayinya di rumah. Selama bayi berada di rumah sakit dan di bawah perawatan tim kesehatan profesional, ibu tidak terlampau khawatir tentang ketidakberdayaannya, akan tetapi, bila bayi sudah dibawa pulang ibu bertanggung jawab atas perawatannya. Ibu yang memiliki bayi prematur merasa tidak mampu memberikan perawatan yang sesuai, oleh karena itu harus meningkatkan kepercayaan dirinya untuk mampu merawat bayinya (Bobak, Lowdermilk, Jensen, \& Perry 2005).

Berdasarkan fenomena yang diamati peneliti, di wilayah kerja Puskesmas Ambacang, kota Padang cukup banyak ditemukan kasus ibu melahirkan bayi berat lahir rendah (BBLR) dan prematur. Studi pendahuluan daerah binaan keperawatan dibawah binaan dinas kesehatan kota Padang, teridentifikasi adanya ibu yang melahirkan bayi prematur dan BBLR dan telah berhasil dalam perawatannya. Usia anak ibu-ibu tersebut telah mencapai usia Balita. Diperkuat dari hasil wawancara dengan kader posyandu di wilayah kerja Puskesmas Ambacang Kota Padang. perawatan di rumah sakit. Ibu yang berhasil merawat bayi premature dan BBLR di rumah merupakan suatu keadaan yang sangat menarik untuk dipelajari, karena dengan pengalaman yang baru mendapatkan bayi premature dan BBLR, ibu telah mampu merawatnya dengan baik. Hal tersebut perlu dikaji secara mendalam gambaran pengalaman ibu dalam merawat bayi prematur di rumah.

\section{METODE}

Jenis penelitian pada penelitian ini adalah penelitian kualitatif. Desainnya adalah studi fenomenologi, yaitu dengan melihat fenomena khusus pengalaman ibu dalam merawat bayi yang prematur di rumah, melalui tiga langkah dalam proses fenomenologi deskriptif, yaitu intuiting, analyzing dan phenomenological describing. Partisipannya berjumlah 5 orang ibu. Kegiatan analisis data dimulai dengan mendengar deskripsi verbal partisipan dan diikuti dengan membaca berulang-ulang hasil transkrip verbatim. Metode analisis induktif dan síntesis yang digunakan dalam penelitian ini menggunakan Colaizzi's Method (Colaizzi,1978 dikutip Strubert dan Carpenter, 1990). 
Untuk menetapkan keabsahan data dalam penelitian kulitatif, ada empat kriteria yang digunakan dalam pelaksanaan tehnik pemeriksaan keabsahan data yaitu credibility (derajat kepercayaan), transferability (keteralihan), dependability (ketergantungan), dan confirmability (kepastian).

\section{HASIL DAN PEMBAHASAN}

Ibu pada umumnya sudah mengetahui bahwa karakteristik bayi prematur dan bayi yang berat badannya lahir rendah cenderung berukuran lebih kecil dibandingkan dengan ukuran atau berat badan bayi yang normal. Hampir semua ibu dapat menyebutkan karakteristik bayi yang lahir prematur dan bayi yang mempunyai berat badan lahir rendah itu berbeda dengan bayi yang lahir cukup bulan. Semua responden dapat mengidentifikasi juga bahwa kelahiran bayi mereka dilahirkan dengan cara yang tidak biasa atau dengan penyebab tertentu. Sebagian responden mengakui bahwa mereka terlalu cape/kecapean sehingga fisik mereka terkuras, ada juga yang mengatakan bahwa kelahirannya cukup bulan tetapi dari awal kehamilan si ibu susah makan dari kedua kelompok ini bisa disimpulkan bahwa responden-responden ini mengalami kekurangan gizi saat kehamilannya. Sebagian lagi menyadari ada penyebab langsung yang patologis sehingga responden harus melakukan tindakan operasi untuk penyelamatan kehamilannya (perdarahan per vaginam) padahal kehamilannya belum cukup bulan.

Respon ibu terhadap kelahiran bayi. Ibu mempunyai respon positif dan negatif terhadap kelahiran bayinya yang prematur dan BBLR ini. Respon positif yang muncul dalam wawancara tersebut adalah ibu segera menerima kenyataan bahwa bayinya telah lahir dengan selamat walaupun keadaannya kurang dari normal. Proses penerimaan ibu bahwa anaknya lahir dengan premature sangat berpengaruh pada kesiapan ibu dalam merawat bayi premature ini. Bila masa penerimaan terlalu lama bahkan ibu terjebak dalam keadaan penolakan (denial) yang cukup lama akan sangat mengancam kelangsungan hidup bayi yang baru saja dilahirkannya. Karena bagaimanapun kondisi kejiwaan ibu sangat berpengaruh besar dalam mengawal bayinya melewati masa-masa pertumbuhan. Berikut ini beberapa cuplikan ungkapan responden terhadap keadaan bayinya yang lahir premature :

Umumnya responden tidak mengalami masa penolakan yang lama dan secepatnya dapat menerima keadaan bahwa bayinya lahir dalam keadaan berbeda dengan umumnya bayi-bayi lain sehingga dengan segera si ibu dapat melanjutkan tahapan perawatan dirinya dan bayinya dengan baik.Pengalaman ibu yang melahirkan bayi prematur muncul berbagai respon, adapun respon negatif yang diungkapkan adanya respon menolak, respon tawar menawar dan respon depresi.

Perawatan bayi premature dan BBLR di rumah. Meskipun umumnya partisipan umumnya melahirkan anak pertama saat melahirkan bayi prematur tetapi mereka memiliki pengetahuan yang cukup tentang perawatan bayi prematur. Pengetahuan mereka itu diperoleh dari penjelasan dari petugas kesehatan baik saat dirawat di rumah sakit maupun saat mereka berobat atau konsultasi di puskesmas/balai pengobatan dan posyandu. Dari ungkapan diatas dapat dilihat bahwa responden telah mendapat tambahan pengetahuan mengenai cara merawat bayi prematur saat dirawat di rumah sakit atau saat berobat ke puskesmas dan tempat pelayanan kesehatan lainnya. Salah satu indikator keberhasilan melakukan perawatan bayi umumnya dan bayi prematur khususnya adalah pengetahuan dan kritis terhadap tahapan tumbuh kembang bayi. Semua responden telah memiliki pengetahuan yang cukup 
tentang tumbuh kembang bayi. Penyataan ibu sudah menggambarkan cukupnya pengetahuan ibu terhadap tumbuh kembang sehingga dengan pengetahuan sederhana seperti ini pun sudah bisa dijadikan salah satu indikator bahwa keberhasilan perawatan bayi prematur sudah mereka dapatkan.

Dukungan dari lingkungan. Dukungan dari orang terdekat bisa menjadikan pasokan semangat bagi orang-orang yang sedang dalam permasalahan atau sedang dalam masa perawatan. Ibu yang melahirkan bayi prematur apalagi cara lahirnya yang melalui operasi (sectio secaria) mengalami masalah ganda, pertama dia sendiri harus melewati masamasa pasca operasi dan bayinya harus mendapat porsi perhatian yang lebih daripada bayi-bayi lain yang lahir dengan normal. Dari lima (lima) partisipan yang menjadi objek penelitian, seluruhnya mendapat perhatian dari orang-orang disekitarnya terutama orang rumah, baik itu orang tua, suami maupun famili lainnya.

Harapan ibu pada petugas kesehatan. Kemampuan ibu untuk dapat merespon dan menilai serta mengungkapkan harapanharapan terhadap pelayanan tenaga kesehatan merupakan gambaran sikap seseorang yang kritis dan tau akan hak yang mesti diterimanya dalam menjalani perawatan diri dan bayinya. Hal ini memperlihatkan kepada kita bahwa kebiasaan orang-orang dahulu yang menerima apapun tanpa protes dan tanpa keinginan yang lain terhadap pelayanan yang diberikan oleh petugas kesehatan sudah tidak nampak. Mereka pada umumnya sudah dapat menilai dan merasakan pelayanan kesehatan yang seperti apa yang seharusnya mereka terima serta pelayanan yang seperti apa yang seharusnya tenaga kesehatan berikan kepada para kliennya. Ungkapan dan pernyataan ibu memberi gambaran bahwa si ibu sudah mengetahui hak-hak apa saja yang layak mereka terima apabila berkunjung ke tempat pelayanan kesehatan. Selain itu semua responden juga mempunyai harapan yang serupa terhadap perilaku para tenaga kesehatan agar dalam merawat kliennya selain memberikan pelayanan yang baik mereka juga harus memberikan pengetahuan dan keterampilan untuk bekal perawatan di rumah setelah menjalani perawatan.

\section{KESIMPULAN DAN SARAN}

Studi fenomenologi pada penelitin ini memperoleh 5 (lima) tema. Tema tersebut adalah: (1) Karakteristik bayi premature dan BBLR, (2) Respon ibu terhadap kelahiran premature dan BBLR (3) Perawatan bayi premature dan BBLR di rumah, (4) Dukungan ibu dalam merawat bayi premature dan BBLR, (5) Harapan ibu pada pelayanan kesehatan.

Kondisi kejiwaan ibu sangat berpengaruh besar dalam mengawal bayinya melewati masa-masa pertumbuhan bayi, sehingga ibu diharapkan mempunyai respon postif terhadap kelahiran bayi prematur. Diharapkan kemampuan ibu untuk dapat merespon dan menilai serta mengungkapkan harapan-harapan terhadap pelayanan tenaga kesehatan merupakan gambaran sikap seseorang yang kritis dan tau akan hak yang mesti diterimanya dalam menjalani perawatan diri dan bayinya. Dukungan dari orang terdekat bisa menjadikan pasokan semangat bagi ibu dalam perawatan bayi prematur

\section{DAFTAR PUSTAKA}

Burns, N. \& Grove, S.K. (2003). Understanding nursing research. $\left(3^{\text {rd }}\right)$. USA : W.B. Saunders Company.

Bobak, I.M., Lowdermik, D.L., \& Jensen, M.D. (2005). Keperawatan maternitas. (Edisi 4). Jakarta: Penerbit EGC. 
Cutrona, C., \& Troutman, B.R. (1986). Social support, infant temperament, and parenting self-efficacy. A mediational model of postpartum depression. Child Development, 57(6), 1507-1518 dalam Badr, L.K. (2005). Further psychometric testing and use of the maternal confidence questionnaire. Comprehensive Pediatric Nursing, 28:163-174.

http://www.proquest.umi.com diperoleh tanggal 20 Januari 2010.

Hockenberry, M. \& Wilson, D. (2009). Wong's nursing care of infants and children. St.Louis: Mosby Elsevier.

Sulani, F. (2009). Masalah pertumbuhan janin terhambat (PJT) dan bayi berat lahir.

Setiawan (2009). Asuhan keperawatan pada bayi hiperbilirubin.Diakses tanggal 24 November 2009. Dari : http://cnennisa.files.wordpress.com/20 07/08/asuhan-keperawatan-denganhiperbilirubin.pdf

Wijayanegara, H. et al. (2009). Prematuritas. Bandung : Penerbit Refika Aditama. 